Journal of Business and Tourism

Volume 05 Number 02

July-December, 2019

\title{
An Empirical Study of Customer Satisfaction and Loyalty: An Evidence of Telecom Sector in Pakistan
}

\author{
Arman Khan \\ Department of Business Administration \\ Shaheed Benazir Bhutto University Shaheed Benazirabad \\ armankhan@sbbusba.edu.pk \\ Javed Ahmed \\ Department of Business Administration \\ Shaheed Benazir Bhutto University Shaheed Benazirabad. \\ Javedahmed@sbbusba.edu.pk \\ Farman Ullah Khan \\ PhD Scholar, Department of Management and Humanities \\ Universiti Teknologi Petronas, Perak, Malaysia \\ farman_ghazni@yahoo.com
}

\begin{abstract}
This research explores key determinants of customer loyalty in a research setting where customer loyalty is a dependent variable and service quality switching costs and switching cost and trust are all independent variables. The research uses a variety of statistical techniques, including reliability factor and regression analysis. As the country is moving fast towards digital financial inclusion. The telecommunication sector in Pakistan has also been impressively keeping up with paced. With the growing fame of digital telecommunications, the evaluation of customer loyalty and satisfaction has become essential for mobile network operators as well as for researchers at the same moment. To define, the variables influencing client satisfaction and loyalty, a comprehensive literature study was conducted. A conceptual research model was created based on a literature review to identify the link between service quality and customer satisfaction, in addition to price switching, customer loyalty and conviction. By using a self-administered questionnaire, the researchers gathered the perceptions of 300 prepaid phone subscribers form four carriers. The findings show that there is a significant direct connection between quality of service and customer satisfaction. Furthermore, the results of the study also demonstrate that customer loyalty is important predictors of quality of service, switching costs, and conviction. Trust is the most crucial determinants of customer loyalty among these three precedents in the context of service-oriented enterprises.
\end{abstract}

Keywords: Pakistan Telecom; Mobile Telecom Operators; Quality of service; Satisfaction; Loyalty.

\section{Introduction}

The ability to draw on the correct target market, to always purchase/sell the product and to provide support for the item which allows more consumers to switch from the alternative goods 
to your item is referred to as brand loyalty.It is often defined as being able to re-proceed to customers ' orders and to check significant assessments and surveys.It improves the company's customer base as more customers go to the services of the company due to the informal presentation of current customers.In reality, the word is not strictly restricted to this since the company's orchestrated strategy is an incessant technique or plan to keep its customers happy with the goal of bringing more business to the company.Through offering company assurances for high-quality products, the company can offer increased benefits through happy and faithful clients.Out of the many ways to achieve loyalty to consumers few are by free offers, blessing vouchers, very low credit charges, swap of inscriptions for better value, service arrangements, discounts, and numerous award programs. Whatever aspect is a definite objective remains for customers to expand, including more customers, who help the company achieve the goal of increasing productivity and providing and holding happy customers with their word of mouth visibility and surveys.Most conventional initiatives inspire consumers to purchase a product, some of which include an unconditional display of the products, discounts for buyers or free plans for a customer.

The organization may also give its customers a safe time to attempt their products, often referred to as brand name devotion, the purpose of all these plans is to inspire the consumer not only to buy the goods from the company over and over but also to try to find a greater selection. The resource for trustworthy clients is the excellent product administration and management of offers.A company that aims at raising customer loyalty will provide leniency for item protection and management because genius customer service is necessary if customer satisfaction is to be sustained and preserved.It allows the company, while maintaining its expected expenses, to adapt to the whines of the consumer in relation to the goods sold, removing the items that are faulty or making full discounts, in the event that the consumers are not happy with the quality of the products.For each business with new or developed current customers, it was less prudent than creating new customers that existing customers not only ensure the fulfillment of current offers but also recept all auxiliary or additional items offered by the company gradually.Customers who are loyal to the products of the business are an important component in holding buyer orders and marketing costs below normal standards.Most companies find the systems of customer service a persuasive instrument of differentiation from rivals. This separation helps create and develop consumer trust through their actions, social relationship, and experience with the product, either during or after use.Consumer the board also offers the companies, which concentrate on consumer continuity, a continuous advantage. This survey has various factors, consequences, and interfaces of consumer devotion. These can be ordered to encourage value, trust, and loyalty to the customer and the price. The performance of administration is a concept defined and clarified by many interpretations. Nevertheless, it is known and understood by an organization that meets its clients ' needs and desires, that greater assistance value must be defined by customers coming from an administration (Metters et al. 2003). This way, the value of administration can mainly be described as customer satisfaction.Reasonable and reliable inquiries suggest that quality of administration requires three measuring elements, state, and conveyance (Rust and Oliver, 1994) or value expressed by contact, physical condition, and outcome (Lee., 2011). The price of the product (the actual winning cost) is known in two parts, namely the goal value and the apparent value (the cost calculated by the shopper) (Jacoby and Olson, 1977).Price can be defined as a price estimate for the consumer in contrast with the value paid for the same product or administration by rivals (Chen et al. 1994). 
Consumer loyalty has frequently been viewed as a significant determinant of dependability. Consumer loyalty is a general frame of mind shaped dependent on the experience after clients buy an item or utilize assistance (Fornell., 1992). Fulfillment is an assessment of our interactiveexperience to date with a professional consultant and is used by consumers to assess their potential experience (Crosby et al., 1990).Completion is a wide-ranging feeling determined by its design and expense, as well as other rational and personal components (Zeithaml and Bitner, 2000).As a major driver of faithfulness, Trust was differentiated (e.g. Chaudhuri and Holbrook, 2001; Garbarino and Johnson, 1999). A consumer who believes in a product must create great mindsets for it, pay the highest rates, remain faithful to it, and disseminate positive information informally(Chaudhuri and Holbrook., 2001). The effect of trust on client dependability turns out to be particularly applicable when stood up to with exchanging choices with a significant level of apparent hazard and vulnerability (Lewis, 2002). Client faithfulness is one of the most significant parts of promoting arranging since client maintenance is a higher priority than client ingestion (Behara et al., 2002). Current customers are responsible for repurchasing products and administrations for a long time (Martensen et al., 2007).Client reliability is known as a real place of business for the age of incomes, while loyal customers are once again regarded as the best people for the item and operational ads (Andreasen and Lindstad., 1998).

Companies should work on price fairness and coverage for their customers. Because these two are the basic ingredient for the strength and growth of the telecom industry. Most people in rural areas always faced this problem of coverage. So,the telecom industry creates such goodwill for its customers by providing them a good coverage with the best possible price fairness.Customer satisfaction is the hallmark for every telecom industry. It is an integration of how customer thinks,feel and act about interacting withparticular product or services. So,the telecom industry always uplifts their services for better effective results and keep focusing on those areas in mind. With a number of licensed key stakeholders, the mobile industry in Pakistan is developing quickly. Pakistan's telecommunications sector's growth rate has been remarkably fast-paced, and help in bringing Mobile Broadband services-3 G, 4 G, LTE, to the nation, and contributing $\$ 4.42$ billion to the National treasury between July-2014 to June-2017.According to the July 2019 the report on statistical of the Pakistan Telecommunication Authority (PTA), the nation's 3G/4 G regular users have gone up to 71 million. Meanwhile, by July 2019, the number of customers on mobile phones has increased to 160 million. 


\section{Cellular Market Share}

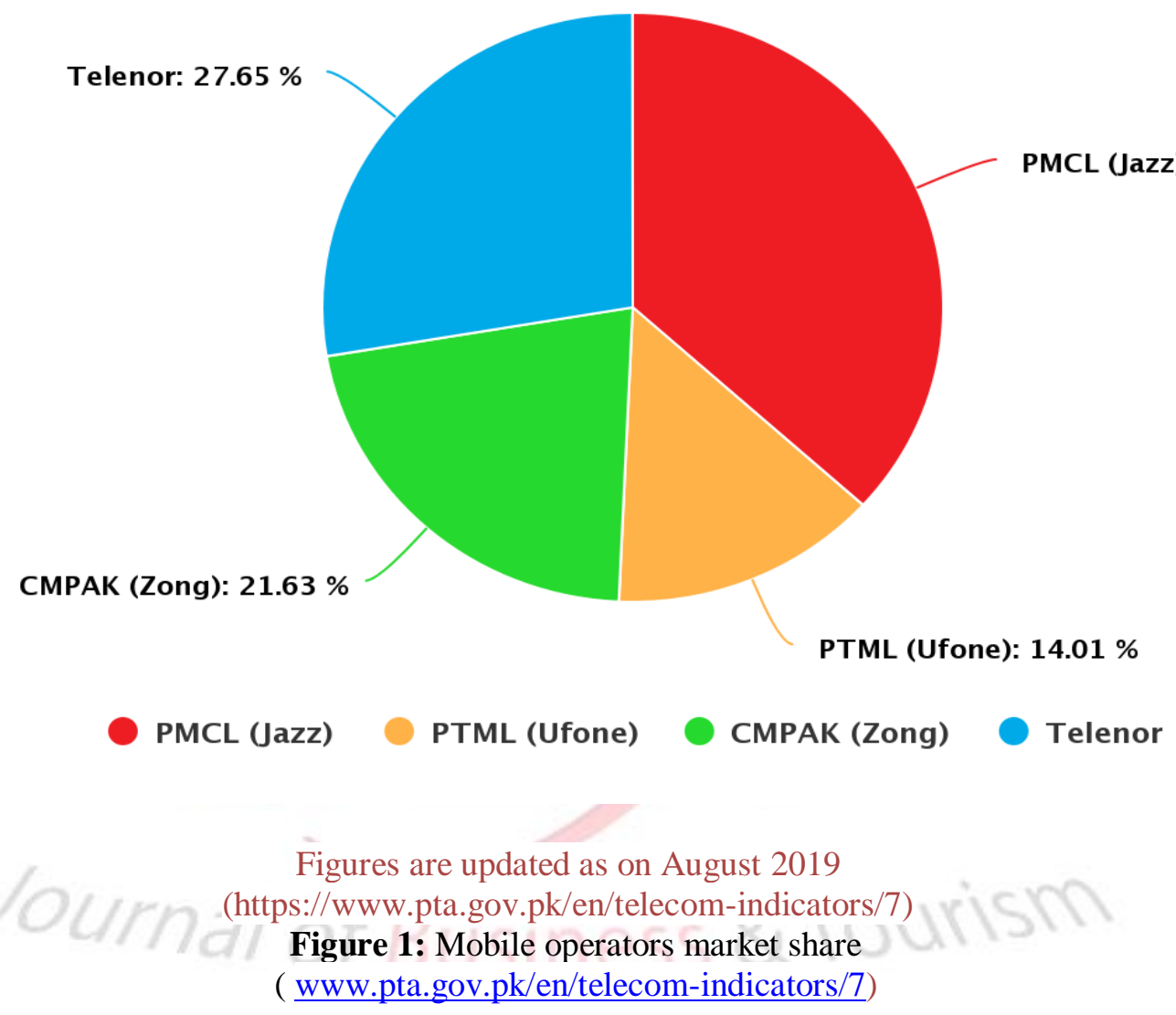

\section{Problem Statement}

Pakistan has made significant developments in the Telecom sector and the Global System for Mobile Communication sector has become extensively competitive. Nowadays there are different options for subscribers, depending on their comfort and accessibility. Therefore the mobile network operators have to exemplify their variables of customer satisfaction and allegiance in order to preserve the leadership positions in the evolving orientation of Pakistan telecom sector.

\section{Significance of the Study}

The research adopts an approach known as linear regression for empirical analysis. The intent of the research was to explore customer satisfaction and client loyalty, simultaneously also foretell the connection between the cost of switching price and trust. Finding this research will assist telecommunication managers in how to get better and boost user contentment \& reliability with services. Assessing different dimensions (i.e. quality of service, price switching \& trust) which will ultimately help managers to better understand their impact on client contentment \&trustworthiness. Lastly, the corporation can better disseminate its infrastructure in order to provide its customers with superior utilities. 


\section{Limitations of the Study}

The research was confined by several variables. Initially, thestudywas restricted in Karachi City alone. Furthermore, the test was conducted on the basis of non-probability sampling. Additionally, the research considers only selective mobile operators. The investigator was unable to integrate telecommunications views from mobile operators and experts in Pakistan as data sources. Finally, from published research in developing nations, the characteristics that affect the perception of consumers towards mobile phone services have been discovered. These results are likely to differ from Pakistan's context.

\section{Literature Review}

There has been extensive study and research on customer satisfaction in the past because it helps to expand and recognize of client dependability,loyalty, satisfaction and their ability to pay (Deng and Sung, 2013).Many researchers pay more attention to quality of service \& consumer satisfaction, For that reasons such as extensive rivalry (Reiheld\&Saser 1990), academician studied the extent of quality \&fulfillment to comprehend client assessment consideration and procedures (Berry, 1988; Olver 1997; Parsurman, \&Zeithaml), Scholarly writing indicates that the assortment of client depends on the difference between a client's prior expectations and his view of the acquisition (Chrchilland Surprnnt1982; Yi, 1990) if the experience of a customer is better than expected, so nearby will be constructive negation of expectations and a complimentary client appraisal is perceived. Service excellence is likewise challenged as a relative feature between user imagined expectations and true insight of customers (Parasuraman et al., 1995). It is known to as the "SERVQUAL Model" in the literature on service quality. It has five basic characteristics or variables which are indicated as follows:

Reliability: faculty to execute the declareintangible services in a reliable and perfect manner. Responsiveness:Readiness and ability to support the customer and provide prompt service. Assurance:Worker's understanding, courteousness and the ability to inspire self-assurance. Empathy:The ability to understand and share customer feelings and needs.

Tangibility: physical appearance, environment, staff cooperation, facility, and availability. Quality and satisfaction are interchangeably used (mutually in industrial and academic world), as these two are fundamentally the same structure of evaluation (Bitner from 1990; Zeithaml from 1996). In the latest research, by using the sculpt established by Oliver et al (1992), Spreng \& Mackoy (1996) investigate the connection linking quality of services and customer satisfaction. This research model integrates these two constructs and indicates that professed quality of service is a stipulation to fulfillment, among other factors. Therefore, the below hypothesis is proposed.

\section{H1:The perceived quality of service and degree of satisfaction has a positive relationship.}

Reichheld (1993) described reliability as being willing to create a sacrifice to reinforce a partnership. The operationalization of adhering structure by the "ACSI (The American Customer Satisfaction Model" derived from the F0rnellet -al., 1996) model is in line with the overall description as it takes economic and quality customer sacrifices while stuck with a particularservice provider. In the above context of telecom based services, Brand loyalty is described as an optimistic predisposition towards a particular network service supplier, resulting in a mixture of the probability of re-buyfrom the same suppliers of extra services and cost tolerance towards their services.

Therefore, the investigators concentrated on customer loyalty determinants being discussed. Boulding et al. (1993) discovered beneficialInteractions between quality of service and repurchase intentions and the readiness to advice on the basis of history and the loyalty 
consequences. In addition, Rust and Zahorik (1993) Address the standards of service quality associated with customer loyalty in banking and insurance (1987). The conclusion is based on strong evidence from academic literature which primarily indicates the connection between quality of service and loyalty to the customer.

\section{H2: The perceived quality of customer service has a positive impact on customer loyalty.}

Research literature on marketing suggests that the cost of the ' loyalty ' switching is due to the actual costs of switching or ambiguity about the worth of product assortment of companies, the costs of changing between service providers, According to Porter (1998), Consumers are facing non-negligible expenses of switching between distinct product or service brands in many industries.The Klemperer classification (1995) demonstrates switching costs, transaction expenses, learning expenses, and simulated or contract expenditure. Transaction cost is associated with establishing an association with a supplier and at times includes the overheads needed to lapse a transaction. Learning cost or expenditure is the endeavoressential by the userto attain the same level of intimacy or installation as an existing product with a new product.Simulatedexchangeoverheads are the expenses generated by means of the company's planned actions and are very much prevalent in the market arena: Examples include regularleafletplan, re-buy discounts and incentives to "click-through". Without suggesting a formal definition of the notion, Fornell (1992) offers a record of variables that may represent these obstacles (i.e. They will prevent clients from having a relationship defect if they are common): search cost, transaction charges, learning outlay, faithful client price cut, client tendency, mentalexertion, heuristics efforts, and the psychological, social and economic risks. The extent of switching costs has been suggested in a specified sector may affect client loyalty (Andrson \& Fornll, 1994; Dick \& Bsu, 1994).

Andreasen 1982-1985,Discovered experiential assistance in connection with medical conveniences of elevated switching cost on customer loyalty. The level of business competition and loyalty in addition to client uncertainty and the market structure (e.g. association drill, client guild, serial tickets for the theater and concert hall) also boost the apparent and real divert costs (Gummesson, 1995). That is to say,Customers who can be expected to show brand loyalty if costs come to trade a number of brands that are not functionally distinctive (Klmprer, 1987).In addition to all, there seems to be a positive connection between both the switching cost level and customer service loyalty. Therefore, the preceding hypothesis is suggested.

\section{H3: The higher the switching cost level, the more the customer loyalty rate is increased.}

In marketing research, thematter of customer confidence has received significant importance as it revealed to have a positive effect on client constancy (Sirdsmukh, et al. 2002). Apsychological state involves the desire to acknowledge insecurity on the basis of the favorable interpretation of other people's intentions or actions.Doney and Cannon (1997) added that a capacity method can build confidence, i.e. the trustee estimates the trustee's capacity to deliver on his commitments. In 1994 Morgan and Hunt indicate that product awareness and equitylead to brand loyalty, as conviction generates highly appreciated for the exchange associations. Therefore, loyalty or engagement is the basis of continuous efforts preserving anesteemed and significant connection generated by confidence (Chaudhuri and Holbrook, 2002). Confidence can be suggested to contribute to engagement as well as allegiance. The following hypothesis was developed as follows:

\section{Hypothesis 4: Trust will have a positive impact on loyalty.}




\section{Conceptual framework}

The article established a conceptual framework for interpretation, and the literature was used as a basis for the conceptual framework (see Figure 1). The primary objective of this paper was to study the predictive capacity and nature as well as strength of the correlation between service quality and customer satisfaction and the secondary objective of the study is to explore service quality, cost change, and customer loyalty. The road map has been designed to better fit into the current research environment. The set definition of the considered factors is summarized below.

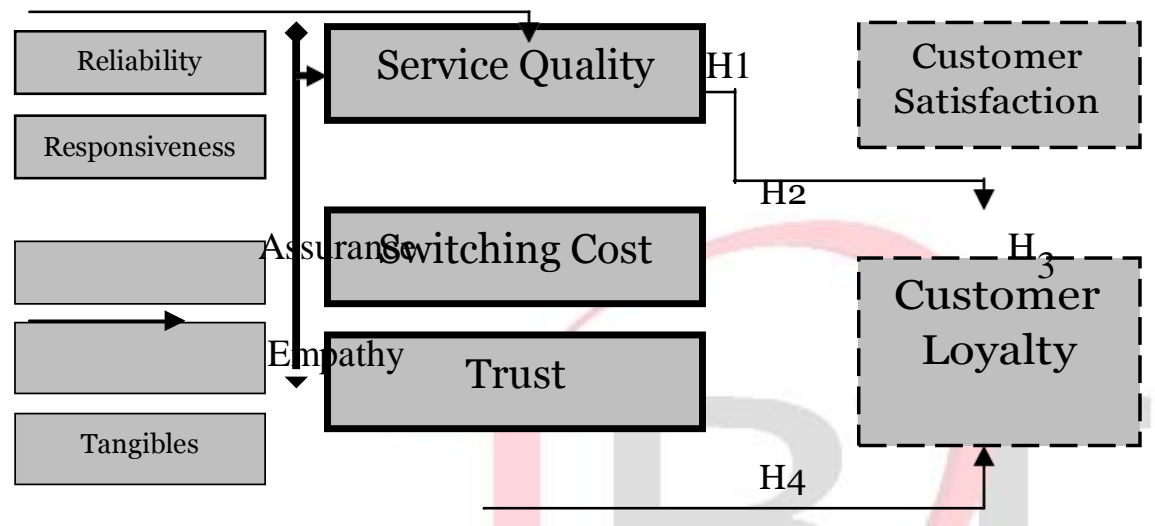

Figure 2: Conceptual-Framework-Model

\section{Research Questions}

The current research problem allows us to answer the following questions.

1. Is there any correlation in the middle of quality of service and customer satisfaction?

2. Is there any linkin the middle of the extent of service and the loyalty of consumer?

3. Is there a linkin the middle of loyalty of customer and changing costs?

4. Is there any linkagein the middle of trust and loyalty of customer?

A number of hypotheses are suggested in line with prior research using the conceptual model:

H1: There is a direct relationship in the middle of customer satisfaction and quality of service .

$\mathrm{H} 2$ :There is a direct linkin the middle of Loyalty of customer and quality of service.

H3: There is a direct correlationin the middle of loyalty of customer and exchange costs.

H4: Trust and consumerloyalty have a direct bond.

\section{Research Methodology}

The research combines main and secondary information. Secondary data were gathered from published literature, publications, brochures, information about the business, etc. A survey questionnaire was used to collect the main information. The target population were mobile subscribers because their using pattern was homogeneous. They were generallyrequired because they were able to best calculate current levels of service. Information was gathered on a convenient basis from 300 prepaid clients from 4 selective mobile operators in Pakistan, including Jazz, Ufone, Zong, and Telenor. Likert scale of five-point ranging from" (1) strong disagreement" to" (5) strong agreement "used to collect the respondent reactions against all items in the survey. Pilot testing was carried out with a group consisting of twenty 30 customers to 
ensure the face and content validity. Problems have been recorded for further alteration, such as unintelligible, compound questions and misconstruction of technical terms.

Reliability \& Study Reliability Validity:

Reliability: A reliability evaluation was performed using Cronbach's alpha to explore whether the paradigms were fully consistent domestically with the current extent or not.A small value of Cronbach's alpha shows that the object model fails to convey the construction that influenced the estimate and vice versa. This study showed a reasonably accurate range for the alpha coefficient of the Cronbach's in 0.7806 that exceeded the minimum (0.70) rates suggested by Nunnally (1978).

Validity: The appropriate literature has been thoroughly examined to guarantee content validity. A pre-test was carried out to check the validity of the list of questions (measure what's meant), comprehensiveness (include all appropriate variable bits and pieces) and readability (making a specific question unlikely to be completely misunderstood).

\section{Data Analysis and Findings}

Linear regression analyses were used to evaluate the above four hypotheses. Referring to hypothesis 1, the regression assessment outcome (Table-1) demonstrates that there is an important linear $(\mathrm{p}=0.000)$ connection among both qualities of services and client satisfaction. Consequently, quality is afundamentalpredictor of consumer satisfaction. It also confirms that the variable quality of service can explain $14.4 \%$ of the variability in satisfaction of the customer.

\section{Table NO 1:}

Linear Associationin the middle of Service Quality and Customer Satisfaction

\begin{tabular}{lll}
\hline S. No & Test/Assessment & Values \\
\hline 1. Model Summary & $\mathrm{R}$ & \\
& $\mathrm{R} \mathrm{Sq}$. & .433 \\
& Adjusted R Sq. \\
& .144 \\
& Std. Error of the Estimate \\
& .531
\end{tabular}

\section{ANOVA}

$\underline{\text { Regression }}$

Residual

$\underline{\text { Total }}$

Sum of squares

72.122

80.341

DF

1

298

299 


\section{Mean Square}

8.221

.242

$\mathrm{F}$

Sig.

.000

Note: Prognosticators: (Constant), Quality of Service, Outcome Variable: Satisfaction

Hypothesis 2 regression assessment shows that there is a important $(\mathrm{p}=0.000)$ link between customer Loyalty and service quality. The quality of serviceis therefore the major anticipate of loyalty of customer (Table NO -2). While the quality of serviceis an important determinant of client loyalty, this variable's explanatory power is quite low. The value of the quality of the variable service will account for only 3.1 percent of the customer loyalty variance.

Table NO -2:

Linear Associationin the middle of Service Quality and Loyalty of Customer

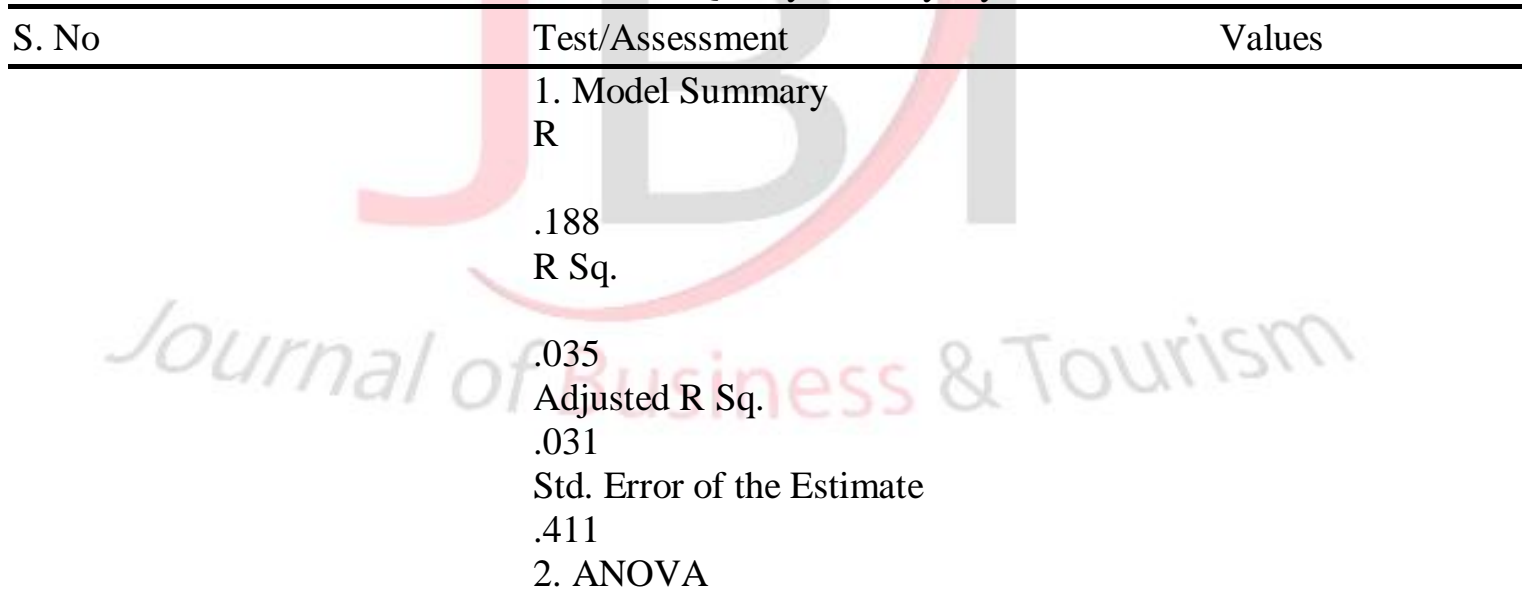

$\underline{\text { Regression }}$

Residual

Total

Sum of squares

77.100

81.018

DF

1 


\section{Mean Square \\ 3.918 \\ .259}

$\mathrm{F}$

Sig.

.000

Note: Prognosticators: (Constant), Quality of Service, Outcome Variable: loyalty of the Customer Hypothesis 3, the regression assessment outcome (Table NO- 3) demonstrates that there is an important linear connection $(\mathrm{p}=0.000)$ between the price of switching and customer loyalty. Therefore, amaindeterminant of loyalty is switching costs. So, themodel summary table-3 also shows that while the cost of switching is anessentialPrognosticatorsof loyalty of the Customer.The explanatory influence of this factor (cost of switching) is relatively low only $10.8 \%$ variation in loyalty can be observed.

Table NO- 3:

Linear Association in The Middle of Switching Cost and loyalty of the Customer

\begin{tabular}{lll}
\hline S. No & Test/Assessment & Values \\
\hline 1. Model Summary & $\mathrm{R}$ & \\
& $\mathrm{R} \mathrm{Sq}$. & \\
& & \\
& Adjusted R Sq. \\
& .108 \\
& Std. Error of the Estimate \\
& .278
\end{tabular}

\section{ANOVA}

.278

$\underline{\text { Regression }}$

Residual

Total

Sum of squares

80.971

87.989

Df

1

298

299 
Mean Square
7.019
.272
$\mathrm{~F}$

25.805

Sig.

.000

Note: Prognosticators: (Constant), Cost of Switching, Outcome Variable: loyalty of the Customer

Hypothesis 4's regression assessment shows that confidence is the important predictor $\mathrm{p}=0.000$ of loyalty of the Customer (Table NO- 4). Therefore, there is an important direct connection among trust and customer loyalty variables. Furthermore, this table shows that the variable trust can explain $30.8 \%$ of the deviation in customer loyalty.

Table NO- 4:

Linear Association in The Middle of Trust and Loyalty of The Customer

\begin{tabular}{lll}
\hline S. No & Test/Assessment & Values \\
\hline & 1. Model Summary \\
$\mathrm{R}$ & .590 \\
& \\
& .348 \\
Adjusted R Sq. & \\
.308 & R Sq. \\
Std. Error of the Estimate & .491 \\
2. ANOVA
\end{tabular}

$\underline{\text { Regression }}$

Residual

$\underline{\text { Total }}$

Sum of squares

61.210

94.310

$\mathrm{DF}$

1

298

299 
Mean Square

33.109

.205

$\mathrm{F}$

161.507

Sig.

.000

Note: Prognosticators: (Constant), Trust, Outcome Variable: Customer Loyalty

\section{Conclusion}

The lifecycle of personal communication is changing rapidly because of theinnovation in telecom technologies so the Mobile telecom operators (MTOs) in Pakistan must have an efficient and effective business model which should focus on creating innovative solutions for the new cultural mindset. Pakistan's telecommunications industry also grew primarily owing to liberalization of doing business and venture, encouraging policies and strong competition. Based on the sector development experience of the past few years, Researchers are looking forward to seeing an outbreak of a telecommunications company in the coming years. It is now becoming an element of our daily lives. It can no longer be ignored by businesses as well as researchers'. One of very few efforts to cope with the topic is the current study. This article adds to this region by constructing a customer satisfaction \& loyalty study model for telecom operators in the country and putting forward four validated assumptions. In addition, to examine these hypotheses, a study technique was used. The outcome demonstrates an important linear connection between the extent of the services of the quality and the satisfaction of the network user. The results of this study showed that two features of service quality, i.e. responsiveness and empa thy, were essential indicators of customer satisfaction in the service- oriented enterprise. The outcome also demonstrates that there are important predictors of customer loyalty for service quality, switching costs and trust variables. In the sense of service-oriented companies, precursors such as trust serve as the key predictors of customer loyalty. From this research, the mobile telecom operators (MTOs) can obtain hints regarding market essential problems which they must be more alert to hold market share, raise it and develop brand equity.

\section{References}

Andreasen, A.R. (1985). "Consumer responses to dissatisfaction in loose monopolies", Journal of Consumer Research, Vol. 12, pp 135-41.

Anderson, J.C. \&Narus, J.A. (1990). "A model of distributor firm and manufacturer firm working partnerships", Journal of Marketing, Vol. 54, January, pp 42-58.

Anderson, E.W. \& Fornell, C. (1994). A framework for comparing customer satisfaction across individuals and product categories. Journal of Economic Psychology, Vol. 12, pp 267-86.

Bitner, Mary J. (1990), "Evaluating Service Encounters: The Effects of Physical Surroundings and Employee Responses," Journal of Marketing, 54 (2), 69-82.

Boulding, W., Kalra, A., Staelin, R., and Zeithaml, V.A. (1993). A dynamic process model of service quality: from expectations to behavioral intentions. Journal of Marketing Research,30, February, pp 7-27.

Cronin, J.J. and Taylor, S.A. (1992). Measuring service quality: a reexamination and Extension. Journal of Marketing, Vol. 56, July, pp 55-68. 
Crosby, L.A. and Stephens, N. (1987). Effects of relationship marketing on satisfaction, retention, and prices in the life insurance industry. Journal of Marketing Research, Vol. 24, pp 40411.

Churchill, G. A. J., Surprenant, C., (1982): An investigation into the determinants of customer satisfaction, Journal of Marketing Research, Vol. 19, No. 4, pp. 491-504.

Chaudhuri, A., and Holbrook, M. B., 2002. Product-Class Effects on Brand Commitment and Brand Outcomes: The Role of Brand Trust and Brand Affect. The Journal of Brand Management 10 (1), 33-58.

Dick, A.S. and Basu, K. (1994). Customer loyalty: toward an integrated conceptual framework. Journal of the Academy of Marketing Science, Vol. 22, pp 99-113.

Doney, P.M. and Cannon, J.P. (1997). An examination of the nature of trust in buyer-seller relationships.

Journal of Marketing, Vol. 61, April, pp 35-51.

Duffy, D. L. (2003). Internal and external factors which affect customers loyalty, Journal of Consumer Marketing, 20, 5, pp 480-485.

Fornell, C. (1992), “A national customer satisfaction barometer: the Swedish experience”, Journal of Marketing, Vol. 56, pp. 6-21.

Fornell, C., Johnson, M.D., Anderson, E.W., Cha, J., and Bryant, B.E. (1996) "The American Customer Satisfaction Index: Nature, purpose, and findings," Journal of Marketing (60:7), pp 7-18.

Gummesson, E. (1995), "Relationship marketing; its role in the service economy", in Glynn W. and Barnes, J.G. (Eds), Understanding Services Management, pp. 244-68.

Klemperer, P. (1995), "Competition when consumers have switching costs: an overview with applications to industrial organization, macroeconomics, and international trade", Review of Economic Studies, Vol. 62, pp. 515-39.

Klemperer, P. D. (1987). Markets with Consumer Switching Costs. Quarterly Journal of Economics, 102(2), 375-394.

Morgan, R.M. and Hunt, S.D. (1994), "The commitment-trust theory of relationship marketing", Journal of Marketing, Vol. 58, July, pp. 20-38.

Oliver, R. L. (1997). Satisfaction: A Behavioral Perspective on the Consumer, McGraw-Hill, New York, NY.

Parasuraman, A., Zeithaml, V. A. \& Berry, L. L. (1988). "SERVQUAL: a multiple-item scale for measuring consumer perceptions of service quality". Journal of Retailing, 64 (Spring), $12-40$.

Parasuraman, A., Zeithml, V.A. and Berry, L.L, 1998., SERVQUAL: A multi-item scale for measuring consumer perceptions of service quality., Journal of Retailing., Spring, PP. 1240

Reichheld FF, Sassar WE (1990). Zero Defections: Quality Comes to Services. Harv. Bus. Rev.

September - October, pp. 105-11

Reichheld, Frederick F. (1993), “Loyalty-Based Management,"Harvard Business Review, 71 (2), 64-73. Rust, R.T. and Zahorik, A.J. (1993), "Customer satisfaction, customer retention, and market share",

Journal of Retailing, Vol. 69, pp. 193-215. 
Rousseau, Denise M., Sim B. Sitkin, Ronald S. Burt and Colin Camerer (1998), „Not so Different After All: A Cross-Discipline View of Trust,“ Academy of Management Review, 23 (3), 393-404.

Shy, O. (2002), “A quick and easy method for estimating switching costs”, International Journal of Industrial Organization, Vol. 20, pp. 71-87.

Singh, J. and Sirdeshmukh, D. (2000), "Agency and trust mechanisms in customer satisfaction and loyalty judgments", Journal of the Academy of Marketing Science, Vol. 28 No. 1, pp. 150-67.

Sirdeshmukh, D., Singh, J. and Sabol, B. (2002), "Consumer trust, value and loyalty in relational exchanges", Journal of Marketing, Vol. 66 No. 1, pp. 15-37.

Spreng, R.A. and Mackoy, R.D. (1996). An empirical examination of a model of perceived service quality and satisfaction, Journal of Retailing, 72(2), pp 201-14.

Sureshchanndra, G.S., Rajendran, C. and Anantharaman, R.N. (2002). The relationship between service quality and customer satisfaction - a factor specific approach, Journal of Service Marketing, 16(4), pp 363-79.

Woodside, A.G., Frey, L.L. and Daly, R.T. (1989), 'Linking service quality, customer satisfaction, and behavioral intention", Journal of Health Care Marketing, Vol. 9, December, pp. 5-17.

Yi, Youjae. 1990. "A Critical Review of Consumer Satisfaction." in Review of Marketing. Ed. Valarie A. Zeithaml. Chicago: American Marketing Association, 68-123.

Zeithaml, Valarie A., Leonard L. Berry, and A. Parasuraman (1996), "The Behavioral Consequences of Service Quality," Journal of Marketing, 60 (2), 31-46. 